EXERO, e-ISSN 2655-1519, p-ISSN 2655-1527, Vol. 02, No. 01, Mei 2019

\title{
KECENDERUNGAN IMPULSE BUYING PADA MAHASISWA DITINJAU \\ DARI LATAR BELAKANG KELUARGA
}

\author{
(Studi Kasus Mahasiswa di Lima Universitas Di Yogyakarta)
}

\author{
Exnasiyah Yahmini \\ Youth Financial Academy, Loan On Card Dept., \\ PT Bank Mega Tbk, Kancab Yogyakarta \\ exnasiayami@gmail.com
}

DOI:doi.org/10.24071/exero.2019.02.01.03

\begin{abstract}
This research aimed to find out the impulsive buying tendency at college students from five universities in Yogyakarta and to discover the difference on the impulsive buying tendency at college students from five universities in Yogyakarta according to their family background including their parents' status and occupations. This research used 100 respondents as the subject of this research. The data collection technique used in this research is Sampling Incidental technique. The instrument tests used in this research are validity and reliability test. The analysis technique used in this research is Independent Sample T-Test. The result of this research shows that the impulsive buying tendency at college students from five universities in Yogyakarta, based on their parents' status, there is no different impulsive buying tendency between those who raised in two-parents family and single-parent family. Meanwhile, based on the parents' occupations background, there is different impulsive buying tendency between those whose parents'occupation is civil servant and those whose are not.
\end{abstract}

Keyword: impulsive buying, purchase behaviour

\section{PENDAHULUAN}

Berdasarkan data proyeksi Badan Pusat Statistik (BPS), pada tahun 2015 lalu jumlah penduduk di Indonesia sekitar 255,18 juta penduduk termasuk di dalamnya adalah jumlah pemuda yang mencapai 62,4 juta orang (www.bps.go.id). Hal ini menunjukkan bahwa rata-rata jumlah pemuda itu 25 persen dari proporsi jumlah penduduk Indonesia secara keseluruhan. Secara umum, jika menggunakan basis data proyeksi jumlah pemuda versi BPS tersebut, maka persebaran jumlah anak muda di Jawa menempati posisi pertama di Indonesia dengan 57,94 persen (Latief, 2015). 
Bagi dunia bisnis dan ekonomi, kehadiran generasi muda adalah hal yang disambut positif bersama strategi yang disiapkan secara tepat untuk mengarah kepada mereka. Perusahaan-perusahaan dituntut untuk hadir secara aktif di media sosial karena sebagian besar generasi muda menghabiskan waktunya di internet dan media sosial. Sebelum memutuskan pembelian suatu produk, generasi muda terlebih dahulu aktif mencari informasi melalui internet maupun sosial media (Ali, 2010).

Dari aspek ekonomi, jumlah generasi muda yang besar menjadi potensi pasar yang menggiurkan. Pola konsumsi yang berubah menjadi berbasis internet harus diperhatikan oleh perusahaan-perusahaan yang menyasar generasi muda. Generasi muda yang ada di Indonesia saat ini sebagian besar merupakan kalangan kelas menengah yang memiliki daya beli tinggi dan memiliki tipe perilaku yang cenderung konsumtif hingga mencapai 62,8\% (https://nasional.sindonews.com/read). Sementara itu, Moningka (2016) mengungkapkan bahwa ada tipe perilaku konsumtif yang salah satunya adalah pembelian impulsif (impulse buying).

Impulse buying merupakan pola perilaku konsumen dalam melakukan kegiatan pembelian suatu produk tanpa adanya tahap perencanaan terlebih dahulu. Perilaku pembelian ini biasanya timbul karena dipengaruhi oleh rasa penasaran dan suasana hati, lingkungan toko, display dan promosi yang ditawarkan. Dalam pembelian produk, perilaku antar konsumen bisa sama atau bisa berbeda. Seorang konsumen sebelum melakukan pembelian produk, ada yang sudah direncanakan dan ada yang belum direncanakan. Perilaku konsumen yang belum melakukan perencanaan dalam pembelian, dapat mendorong untuk melakukan pembelian spontan (impulse buying).

Menurut Coley (dalam Mulyono, 2012: 92- 93), impulse buying sudah terjadi sejak tahun 1896 ketika Weles menyatakan bahwa sembilan dari sepuluh orang melakukan pembelian impulsif (impulse buying). Melihat banyaknya orang impulsif dalam pembelian produk serta sifat pembelian impulsif yang mudah menular, maka tidak heran jika semakin banyak fokus pemasar ditujukan kepada pembelian impulsif, terutama dikarenakan perilaku pembelian impulsif dipengaruhi oleh keadaan internal diri (calon) konsumen maupun keadaan eksternal konsumen (Coley dan Burgess, 2003: 284). 
Sementara itu, Kotler dan Amstrong (2008: 236) mengungkapkan bahwa demografi merupakan salah satu segmentasi pasar konsumen. Dalam segmentasi demografis Kotler dan Keller (2009: 236) pasar dibagi dalam beberapa kelompok berdasarkan variabel usia, ukuran keluarga, siklus hidup keluarga, jenis kelamin, penghasilan, pekerjaan, pendidikan, agama, ras, generasi, kebangsaan dan kelas sosial. Alasan variabel demografis begitu populer bagi pemasar adalah bahwa sangat erat kaitannya dengan kebutuhan dan keinginan konsumen. Variabel yang paling memberikan pengaruh pada keputusan pembelian serta menjadi hal yang paling menarik bagi pemasar antara lain adalah keluarga dan status pekerjaan.

Di sisi lain, variabel lain yang mempengaruhi yaitu keluarga. Kotler dan Keller (2009: 171) menyatakan bahwa keluarga merupakan organisasi pembelian konsumen yang paling penting dalam masyarakat dimana anggota keluarga mempresentasikan kelompok referensi utama yang paling berpengaruh. Keluarga (family) adalah sumber pengaruh sosial terpenting bagi sebagian besar konsumen, khususnya bisa keluarga luas terlibat. Keluarga berperan sebagai agen sosialisasi utama, membantu anggota-anggotanya mendapatkan keahlian, pengetahuan dan sikap untuk bertindak sebagai konsumen di pasar. Akibatnya keluarga memiliki pengaruh besar dan abadi pada sikap anggota-anggota yang lebih muda terhadap berbagai produk, merek, dan toko. Ada kecenderungan bahwa banyak produk dan jasa yang dibeli oleh generasi berikutnya yang dipengaruhi oleh orang tua bahkan kakek-nenek (Boyd, Walker, Larrece : 2000). Selanjutnya, menurut Setiadi (2003: 208), keluarga adalah variabel yang paling mempengaruhi keputusan pembelian pada suatu produk. Keluarga memiliki pendapatan rata-rata yang lebih tinggi dibandingkan denggan rumah tangga sebab jumlah yang lebih banyak dibandingkan dengan individu yang bekerja dalam suatu keluarga.

Penelitian ini mencoba melihat bagaimana kecenderungan impulse buying pada mahasiswa di lima universitas di Yogyakarta dan apakah ada perbedaan kecenderungan impulse buying pada mahasiswa tersebut apabila ditinjau dari latar belakang keluarga (status orang tua dan latar belakang pekerjaan orang tua) dengan berfokus pada status orang tua dalam kaitanya orang tua lengkap dan orang tua tunggal (single parent) dan latar belakang pekerjaan orang tua dalam kaitannya PNS/Polisi/ABRI, Non-PNS (karyawan swasta, buruh) dan Wiraswasta. 


\section{KAJIAN PUSTAKA}

\section{Latar Belakang Keluarga}

Keluarga (family) adalah sumber pengaruh sosial terpenting bagi sebagian besar konsumen, khususnya bila keluarga luas terlibat. Keluarga berperan sebagai agen sosialisasi utama, membantu anggota-anggotanya mendapatkan keahlian, pengetahuan dan sikap untuk bertindak sebagai konsumen di pasar. Akibatnya keluarga memiliki pengaruh besar dan abadi pada sikap anggota-anggota yang lebih muda terhadap berbagai produk, merek, dan toko. Ada kecenderungan bahwa banyak produk dan jasa yang dibeli oleh generasi berikutnya yang dipengaruhi oleh orang tua bahkan kakek-nenek (Boyd, Walker.Larrece : 2000). Sementara itu, Kotler dan Keller (2009: 171) mengungkapkan bahwa keluarga adalah organisasi pembelian konsumen yang paling penting dalam masyarakat dimana anggota keluarga mempresentasikan kelompok referensi utama yang paling berpengaruh.

\section{Status Orang Tua}

Berdasarkan kelengkapan anggota keluarga terdapat dua bentuk struktur keluarga (status orang tua) menurut Gerungan (2004) yaitu: orang tua lengkap (keluarga utuh) dimana peran ayah dan ibu dalam keluarga menunjukan bahwa kehadiran ayah dan ibu bukan hanya normal, tapi juga esensial. Keluarga yang mempunyai orang tua lengkap akan dapat menjalankanfungsinya dengan baik. Struktur keluarga yang utuh dan harmonis akan memberikan dampak positif bagi perkembangan anak, sehingga hal tersebut akan sangat membantu bagi kesuksesan proses sosialisasi konsumen (Moschis, 1991). Beberapa literatur menyatakan bahwa proses sosialisasi dan stimulus pemasaran kepada konsumen cenderung akan berjalan dengan lancar pada sebuah keluarga yang utuh dan harmonis (Utami, 2011).

Peran orang tua sebagai ayah dan ibu adalah mengasuh, membimbing, dan menjaga anak-anaknya. Namun dikehidupan keluarga yang sering kita jumpai terdapat orang tua yang salah satunya tidak ada, baik itu karena perceraian maupun kematian. Keadaan ini menimbulkan dengan apa yang disebut single parent. Orang tua tunggal (keluarga single parent), dimana keluarga yang orang tuanya cerai sangat mempengaruhi perilaku remaja dan perkembangan remaja, terutama dari segi 
emosional dan kejiwaannya. Tidak dapat dipungkiri bahwa melalui keluargalah seorang anak mendapatkan bimbingan, pendidikan dan pengarahan. Masing-masing kelompok baik itu orang tua lengkap atau orang tua tunggal juga mempunyai kumpulan kebutuhan dan kebiasaan pembelian yang berbeda.

Berdasarkan uraian diatas terlihat bahwa peran serta orang tua dari keluarga dengan orang tua lengkap dan orang tua tunggal memiliki perbedaan dalam perkembangan remaja dan perilaku remaja. Keluarga dengan orang tua tunggal memiliki pengaruh yang kuat akan perkembangan dan perilaku remaja, terutama dari segi emosional dan kejiwaannya. Setiap kelompok keluarga juga akan memiliki kumpulan kebutuhan dan kebiasaan pembelian yang berbeda.

\section{Latar Belakang Pekerjaan Orang Tua}

Perilaku konsumen pada setiap individu berbeda-beda. Perbedaan ini dapat dipengaruhi oleh status pekerjaan (latar belakang pekerjaan orang tua). Dari perbedaan latar belakang pekerjaan orang tua ini maka penghasilan yang didapatkan juga berbeda-beda dan berpengaruh pada jumlah uang saku yang diberikan kepada seorang anak. Perbedaan ini akan mempengaruhi gaya hidup dan pergaulan orang termasuk mahasiswa yang sebagian besar masih menerima uang saku dari orang tua.

Santrock (2003) menyatakan bahwa status sosial ekonomi atau kelas sosial adalah mengelompokan orang-orang berdasarkan pekerjaan, pendidikan, dan karakter ekonomi yang serupa. Pekerjaan merupakan profesi yang disandang seseorang dalam melakukan aktivitas yang memberikan hasil baik berupa pengalaman atau materi yang dapat menunjang kehidupannya (Puspitasari, 2014: 6). Di dalam keluarga, pekerjaan orangtua dapat mempengaruhi sikap seseorang dalam melakukan kegiatan untuk memenuhi kebutuhan dan keinginan seperti berbelanja (Widayati, 2012: 92).

\section{Keputusan Pembelian}

Keputusan pembelian merupakan kegiatan individu dalam menentukan keputusan akan pembelian suatu produk. Definisi keputusan pembelian menurut Kotler (2005: 202) adalah suatu tahap dimana konsumen telah memiliki pilihan dan siap untuk melakukan pembelian atau pertukaran antara uang dan janji untuk 
membayar dengan hak kepemilikan atau penggunaan suatu barang atau jasa. Menurut Kotler dan Amstrong (2008:181), di dalam keputusan pembelian terdapat dua faktor yang bisa berada antara niat pembelian dan keputusan pembelian. Keputusan untuk membeli bisa mengarah kepada bagaimana proses dalam pengambilan keputusan dilakukan. Proses pengambilan keputusan pembelian digolongkan sebagai berikut:

a. Fully Planned Purchase, merupakan proses pembelian terhadap produk dan merek yang sudah dipilih sebelumnya. Kegiatan ini terjadi ketika keterlibatan dengan produk tinggi (barang otomotif) namun juga bisa terjadi dengan keterlibatan pembelian yang rendah (kebutuhan rumah tangga). Planned purchase dapat dialihkan dengan taktik marketing seperti pengurangan harga, kupon, dan aktivitas promosi lainnya.

b. Partially Planned Purchase, yaitu suatu keadaan dimana konsumen bermaksud untuk membeli produk yang sudah ada tetapi pemilihan merek ditunda sampai saat pembelanjaan. Keputusan akhir konsumen dapat dipengaruhi oleh diskon harga dan display pada suatu produk.

c. Unplanned Purchase, yaitu suatu keadaan dimana suatu produk dipilih ditempat pembelian. Konsumen sering memanfaatkan katalog dan produk pada display sebagai pengganti daftar belanja. Taktik tersebut merupakan cara yang mampu memicu pembelian konsumen.

\section{Impulse Buying}

Menurut Cobb and Hoyer (1986), pembelian impulsif seringkali melibatkan komponen hedonic atau affective. Pembelian impulsif terjadi ketika konsumen merasakan adanya dorongan yang kuat untuk membeli sesuatu dengan segera. Dorongan yang dirasakan oleh konsumen berkaitan dengan motivasi konsumen untuk membeli barang secara hedonic yang menimbulkan konflik emosional.

Selanjutnya, Mowen dan Minor (2001) menyatakan bahwa pembelian impulsif adalah tindakan membeli yang dilakukan tanpa memiliki masalah berupa maksud atau niat membeli yang terbentuk sebelum memasuki toko. Pembelian impulsif merupakan pilihan yang dibuat pada saat konsumen melakukan pembelian karena perasaan positif yang kuat mengenai suatu benda. 
Di sisi lain, Rook (dalam Verplaken, 2001) menyatakan bahwa pembelian impulsif (impulse buying) merupakan pembelian yang tidak rasional dan pembelian yang cepat serta tidak direncanakan, diikuti dengan adanya konflik pikiran dan dorongan emosional. Dorongan emosional tersebut berhubungan dengan adanya perasaan yang mendalam yang ditunjukkan dengan melakukan pembelian karena adanya dorongan untuk membeli suatu produk dengan cepat, mengabaikan konsekuensi negatif, merasakan kepuasan dan mengalami konflik dalam pemikiran.

Berdasarkan pemaparan definisi para ahli diatas maka pembelian impulsif (impulse buying) dapat dikatakan sebagai perilaku konsumen dalam membeli suatu produk tanpa adanya perencanaan. Pembelian impulsif timbul karena adanya dorongan emosional individu akan ketertarikan pada suatu produk tanpa berpikir panjang. Menurut Rook (dalam Herliyani, 2017: 24), pembelian impulsif (impulse buying) memiliki beberapa karakteristik sebagai berikut:

a. Spontanitas yaitu pembelian yang timbul karena adanya suatu dorongan secara tiba-tiba, tidak diharapkandan dapat memotivasi konsumen untuk membeli saat itu juga, serta memiliki respon yang menggebu terhadap stimulasi visual langsung ditempat penjualan.

b. Kekuatan, Kompulsi, dan Intensitas dimana kemungkinan terdapat motivasi untukmengesampingkan semua hal dan bertindak dengan seketika.

c. Kegairahan dan Stimulasi, yaitu terdapat desakan secara mendadak untuk membeli barang yang disertai emosi yang tidak terkendali dengan ciri yang menggairahkan,menggetarkan atau liar.

d. Ketidak pedulian akan akibat, yaitu terdapat desakan untuk membeli barang yang sulit untuk ditolak sehingga akibat negatif lebih sering diabaikan.

Menurut Thai (dalam Herliyani, 2017: 25), faktor-faktor yang mempengaruhi impulse buying adalah sebagai berikut :

a. Kondisi mood dan emosi konsumen, keadaan mood konsumen dapat mempengaruhi perilaku konsumen. Misalnya kondisi mood konsumen yang sedang senang atau sedih. Konsumen yang memiliki mood negatif cenderung memiliki impulse buying yang tinggi dengan tujuan untuk mengurangi kondisi mood yang negatif. 
b. Pengaruh lingkungan, Orang-orang yang berada dalam kelompok dengan kecenderungan impulse buying yang tinggi maka akan cenderung terpengaruh untuk melakukan pembelian impulsif.

c. Kategori produk dan pengaruh toko, Produk-produk yang cenderung dibeli secara impulse adalah produk yang memiliki tampilan menarik (bau yang menyenangkan, warna yang menarik), cara memasarkannya, tempat dimana produk ini dijual. Tampilan toko yang menarik akan lebih menimbulkan dorongan pembelian secara impulse.

d. Variabel demografis seperti kondisi tempat tinggal dan status sosial, konsumen yang tinggal di kota memiliki kecenderungan impulse buying yang tinggi daripada konsumen yang tinggal di daerah pinggiran kota.

e. Variabel kepribadian individu, kepribadian individu memiliki pengaruh terhadap kecenderungan impulse buying.

\section{Proses Psikologis dalam Impulse Buying}

Menurut Coley dan Burgess (dalam Mulyono, 2013: 90), pembuatan keputusan dalam pembelian impulsif dipengaruhi oleh masalah kognisi dan afeksi dalam diri seseorang, di mana segi afeksi lebih menonjol dibandingkan sisi kognisi yang ada yang lebih banyak dipengaruhi oleh stimuli eksternal berkaitan dengan faktor harga.

Menurut Silvera et.al. (dalam Mulyono, 2013: 90), pembelian impulsif (impulse buying) pada dasarnya dilakukan oleh banyak orang untuk mengurangi mood atau perasaan negatif karena kegagalan akan sesuatu atau membuat diri mereka lebih baik. Karena dasarnya seperti ini, maka tidak heranjika pasca pembelian impulsif, konsumen dapat mengalami ketidakpuasan atas produkyang telah dibelinya, tetapi ia tetap dapat merasa puas atas pembelian yang telah dilakukannya (Kim dalam Mulyono, 2013: 90). Pengalaman menunjukkan bahwa ketika produk sudah dibeli muncul perasaan bersalah, tetapi kesadaran tersebut kemudian ditutupi oleh pembenaran diri bahwa produk tersebut akan berguna kelak di masa depan. Dalam diri setiap manusia, segi kognisi maupun afeksi tidak dapat dianggap saling bebas karena dalam banyak hal ketika seseorang sedang berada dalam proses pengambilan keputusan, kedua segi tersebut sering konflik sehingga besaran derajat impulsivitas yang ada ditentukan oleh pengatasan segi satu terhadap segi lainnya. 
Pembelian impulsif dalam penelitian ini terdiri dari dua dimensi, yaitu dimensi kognitif dan dimensi afektif. Menurut Coley (dalam Mulyono, 2013: 90). Proses psikologis dalam pembelian impulsif terdiri dari dua proses yang meliputi:

1)Proses Afektif: yaitu proses psikologis dalam diri seseorang yang merujuk kepada emosi, perasaan maupun suasana hati $(\mathrm{mood})$. Proses ini memiliki tiga komponen, yaitu:

a. Irresistible Urge to Buy yaitu suatu keadaan dimana (calon) konsumen memiliki keinginan yang instan, terus menerus dan begitu memaksa, sehingga (calon) konsumen tidak dapat menahan dirinya.

b. Positive Buying Emotion yaitu suatu keadaan dimana (calon) konsumen memiliki suasana hati positif yang berasal dari motivasinya untuk memuaskan diri melalui pembelian impulsif.

c. Mood Management yaitu suatu keadaan di mana muncul keinginan (calon) konsumen untuk mengubah atau menata perasaanya melalui pembelian impulsif.

2)Proses Kognitif: yaitu proses psikologis seseorang yang merujuk kepada struktur dan proses mental yang meliputi pemikiran, pemahaman dan penginterpretasian. Proses ini terdiri dari tiga komponen, yaitu:

d. Cognitive Deliberation yaitu suatu keadaan di mana (calon) konsumen merasakan adanya desakan untuk bertindak tanpa adanya pertimbangan mendalam atau memikirkan konsekuensinya.

e. Unplanned Buying yaitu suatu keadaan di mana (calon) konsumen tidak memiliki rencana yang jelas dalam berbelanja

f. Disregard for the future yaitu suatu keadaaan dimana (calon) konsumen dalam melakukan pembelian impulsifnya tidak menghiraukan masa depan. 


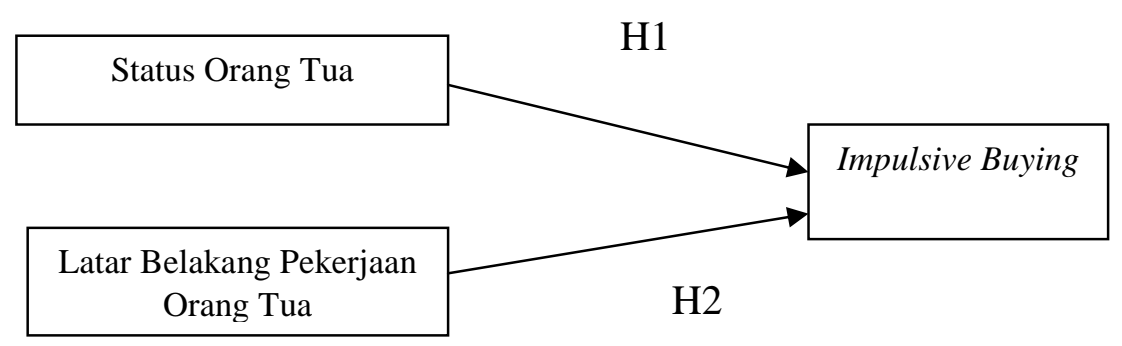

\section{Gambar 1. Kerangka Konseptual Pemikiran}

\section{Rumusan Hipotesis}

Setiadi (2003: 208) mengartikan keluarga sebagai variabel yang paling mempengaruhi keputusan pembelian pada suatu produk. Keluarga memiliki pengaruh yang sangat penting terhadap perilaku konsumen (individu). Berdasarkan kelengkapan anggota keluarga terdapat dua bentuk struktur keluarga (status orang tua) yaitu orang tua tunggal (keluarga single parent) dan orang tua lengkap, Gerungan (2004). Menurut Boyd, Walker, dan Larrece (2000), ada kecenderungan bahwa banyak produk dan jasa yang dibeli oleh generasi berikutnya yang dipengaruhi oleh orang tua bahkan kakek-nenek. Demikian dapat dihipotesiskan bahwa:

\section{$\mathrm{H}_{1}$ : Ada perbedaan kecenderungan impulse buying pada mahasiswa ditinjau dari status orang tua “Orang Tua Lengkap” dan “Orang Tua Tunggal"' (single parent).}

Menurut Santrock (2003), status sosial ekonomi atau kelas sosial adalah mengelompokan orang-orang berdasarkan pekerjaan, pendidikan, dan karakter ekonomi yang serupa. Di dalam keluarga, pekerjaan orangtua dapat mempengaruhi sikap seseorang dalam melakukan kegiatan untuk memenuhi kebutuhan dan keinginan seperti berbelanja (Widayati, 2012: 92). Selanjutnya Mai et.al. (2003: 20) menyebutkan bahwa mereka yang memiliki penghasilan dan pekerjaan dengan jabatan tinggi terbukti cenderung lebih impulsif dibandingkan mereka yang berpenghasilan rendah. Menurut hasil penelitian Herliyani (2017), ada perbedaan 
kecenderungan pembelian impulsif antara latar belakang pekerjaan orang tua PNS dan Non-PNS. Dengan demikian dapat dihipotesiskan bahwa:

\section{H2: Ada perbedaan kecenderungan impulse buying pada mahasiswa ditinjau dari latar belakang pekerjaan orang tua PNS dan Non-PNS.}

\section{METODE PENELITIAN}

Penelitian ini adalah penelitan komparatif untuk menguji perbedaan antara dua kelompok atau lebih. Subjek dalam penelitian ini adalah sebagian mahasiswa Universitas Gadjah Mada, Universitas Muhammadiyah Yogyakarta, Universitas Islam Negeri Sunan Kalijaga, Universitas Sanata Dharma, dan Universitas Sarjana Wiyata Taman Siswa yang menjadi responden. Objek penelitian ini adalah latar belakang keluarga dan kecenderungan impulse buying yang terdiri dari dimensi afeksi dan kognisi. Penelitian dilakukan pada bulan Desember 2017.

Variabel penelitian ini adalah latar belakang keluarga yang meliputi status orang tua dan latar belakang pekerjaan orang tua sebagai variabel bebas dan variabel terikat yang digunakan adalah impulse buying dilihat dari dua dimensi, yaitu dimensi afeksi dan kognisi. Pembagian ke dalam dua dimensi ini merujuk kepada dimensi yang telah digunakan oleh Coley dan Burgess (2003), yaitu dimensi afeksi terdiri dari aspek irresistible urge to buy, positive buying emotions, dan mood management. Dimensi kedua yaitu kognisi yang terdiri dari tiga aspek mencakup cognitive deliberation, unplanned buying, dan disregard for the future. Pengukuran variabel dalam penelitian ini menggunakan skala likert yang dimodifikasi dengan menghilangkan alternatif jawaban atas pernyataan netral untuk menghindari kecenderungan responden memilih jawaban netral.

Populasi dalam penelitian ini adalah semua mahasiswa di 5 universitas di Yogyakarta dengan jumlah mahasiswa sebanyak 97.695. Lima universitas tersebut dipilih berdasarkan jumlah mahasiswa terbanyak per Tahun Ajaran 2016/2017. Dari setiap kelompok universitas negeri dan swasta yang masing masing mewakili sub kelompok universitas berbasis nasionalis dan agama. Data diperoleh dari https://forlap.ristekdikti.go.id/. Kelompok universitas negeri adalah Universitas Gadjah Mada, Universitas Islam Negeri Sunan Kalijaga. Kelompok universitas 
swasta yang dipilih adalah Universitas Muhammadiyah Yogyakarta, Universitas Sanata Dharma, dan Universitas Sarjana Wiyata Taman Siswa.

Dengan tingkat kepercayaan 95\% dan tingkat error sebesar 10\% maka jumlah sampel yang diperlukan sebanyak 96, dan dibulatkan menjadi sebanyak 100 responden. Pendistribusian sampel dilakukan berdasarkan pada proporsi jumlah mahasiswa di setiap universitas, Teknik pengambilan sampel yang digunakan dalam penelitian ini adalah sampling insidental. Instrumen penelitian yang digunakan adalah koesioner. Instrumen diuji validitas dan Reabilitas dengan menggunakan Product Moment dari Pearson (Widoyoko, 2015: 147) dan Cronbach's Alpha. Hasil pengujian menunjukkan bahwa instrumen penelitian valid dan reliabel. Selanjutnya data-data dianalisis dengan menggunakan statistik deskriptif untuk mendeskripsikan atau memberi gambaran terhadap objek yang diteliti. Hipotesisi diuji dengan statistik inferensial t-test sample independent.

\section{HASIL ANALISIS DAN PEMBAHASAN}

Hasil penelitian menunjukkan bahwa dari 100 responden yang dijadikan sampel dalam penelitian terdapat 93 responden atau $93 \%$ adalah responden berstatus orang tua lengkap, sedangkan 7 responden atau 7\% adalah responden berstatus orang tua tunggal. Responden yang memiliki latar belakang pekerjaan orang tua PNS sebanyak 37 responden atau $37 \%$ dan yang pekerjaan orang tua Non-PNS $31 \%$, sedang pekerjaan orang tua Wiraswasta dengan $29 \%$. Responden yang menjawab pekerjaan orang tua dengan jawaban "lainnya" sebanyak $3 \%$.

Berdasarkan perhitungan skor impulse buying adalah sebesar 2,44. Pada skor pengkategorian nilai dari rata-rata dimensi item ini berada pada rentang nilai/skor 1,75 s/d 2,50. Nilai rata-rata tersebut menunjukkan bahwa pada mahasiswa di lima universitas Yogyakarta memiliki kecenderungan impulse buying yang lemah/rendah artinya responden dalam penelitian ini sebelum melakukan pembelian pada barang atau jasa yang ingin dibeli telah melakukan pertimbangan atau membuat rencana terlebih dahulu. 
Tabel 1. Mean Kecenderungan Impulse Buying

\begin{tabular}{|c|c|c|c|}
\hline Variabel & Mean & Dimensi & Mean \\
\hline \multirow{6}{*}{ Impulse buying } & \multirow{6}{*}{2,44} & Irresistible Urge to Buy & 2,34 \\
\hline & & Positive Buying Emotions & 2,68 \\
\hline & & Mood Management & 2,59 \\
\hline & & Cognitive Deliberation & 2,03 \\
\hline & & Unplanned Buying & 2,36 \\
\hline & & Disregard for The Future & 2,07 \\
\hline
\end{tabular}

\section{Pengujian Hipotesis}

Setelah dilakukan pengujian normalitas dan homogenitas data yang hasilnya menyatakan data berdistribusi normal dan homogen, selanjutnya dilakukan pengujian beda rata-rata dengan Independent Sample t-test. Hasil pengujian hipotesis pertama yang berbunyi ada perbedaan kecenderungan impulse buying pada mahasiswa ditinjau dari status orang tua "Orang Tua Lengkap" dan "Orang Tua Tunggal" (Single Parent) dengan uji Independent Sample t-test menemukan bahwa bahwa nilai sig.(2-tailed)sebesar 0,920 > dari 0,05 sebagaimana tersaji pada Tabel 2.

Tabel 2. Hasil Uji Independent Sample T-Test ditinjau dari Status Orang Tua

\begin{tabular}{cccc}
\hline & $\begin{array}{c}\text { Nilai rata-rata kecenderungan } \\
\text { impulsive buying mahasiswa } \\
\text { Status Orang Tua Lengkap }\end{array}$ & $\begin{array}{c}\text { Nilai rata-rata kecenderungan } \\
\text { impulsive buying mahasiswa } \\
\text { Status Orang Tua Tunggal }\end{array}$ & $\begin{array}{l}\text { Sig } \\
\text { tailed) }\end{array}$ \\
\hline $\begin{array}{c}\text { Status Orang } \\
\text { Tua }\end{array}$ & 2,444 & 2,428 & 0,920 \\
\hline
\end{tabular}

Sumber : Hasil Olah Data Primer 2018

Berdasarkan hal tersebut maka dapat dikatakan bahwa hipotesis yang menyatakan ada perbedaan kecenderungan impulse buying pada mahasiswa ditinjau dari status orang tua "Orang Tua Lengkap" dan "Orang Tua Tunggal" (Single Parent) tidak dapat diterima. Hal ini berbeda dengan hasil penelitian Utami (2011) dimana untuk beberapa kasus, proses sosialisasi tertentu kepada konsumen tidak 
mempertimbangkan adanya perbedaan status orang tua. Dengan demikian, bagi pemasar atau pemilik perusahaan, tidak perlu membuat stimulus pemasaran yang berbeda untuk mahasiswa dengan status orang tua Orang Tua Lengkap dan Orang Tua Tunggal (Single Parent).

Pada Tabel 3, hasil pengujian beda rata-rata terhadap hipotesis kedua yakni ada perbedaan kecenderungan impulse buying pada mahasiswa ditinjau dari latar belakang pekerjaan orang tua PNS dan Non-PNS menunjukkan bahwa nilai sig.(2tailed) sebesar $0,005<0,05$ sehingga hipotesis tersebut diterima. Artinya ada perbedaan kecenderungan impulse buying pada mahasiswa dari latar belakang pekerjaan orang tua sebagai PNS dan Non-PNS.

Tabel 3, Hasil Uji Independent Sample t-Test ditinjau dari Latar Belakang Pekerjaan Orang Tua

\begin{tabular}{cccc}
\hline & $\begin{array}{c}\text { Nilai rata-rata kecenderungan } \\
\text { impulsive buying mahasiswa } \\
\text { Latar Belakang Pekerjaan Orang } \\
\text { Tua (PNS) }\end{array}$ & $\begin{array}{c}\text { Nilai rata-rata kecenderungan } \\
\text { impulsive buying mahasiswa } \\
\text { Latar Belakang Pekerjaan Orang } \\
\text { Tua (Non-PNS) }\end{array}$ & $\begin{array}{c}\text { Sig } \\
\text { tailed) }\end{array}$ \\
\hline $\begin{array}{c}\text { Latar } \\
\begin{array}{c}\text { Belakang } \\
\text { Pekerjaan } \\
\text { Orang Tua }\end{array}\end{array}$ & 2,590 & 2,355 & 0,005 \\
\hline
\end{tabular}

Sumber : Hasil Olah Data Primer 2018

Perbedaan perilaku impulse buying mahasiswa terlihat pada latar belakang pekerjaan orang tua yang berbeda. Mahasiswa dengan latar belakang pekerjaan orang tua sebagai PNS lebih tinggi dalam kecenderungan impulse buying daripada mahasiswa dengan latar belakang pekerjaan orang tua sebagai Non-PNS. Ini kemungkinan disebabkan oleh penghasilan yang berbeda yang didapat dari jenis pekerjaan yang berbeda. Penghasilan yang berbeda memberikan kemungkinan jumlah uang saku yang diberikan kepada seorang anak dalam hal ini mahasiswa akan berbeda pula. Dengan perbedaan ini maka akan mempengaruhi gaya hidup dan pergaulan seorang anak termasuk mahasiswa/i yang sebagian besar masih menerima uang saku dari orang tua. hasil dari penelitian ini menunjukkan bahwa mahasiswa dengan latar belakang pekerjaan orang tua sebagai PNS lebih tinggi dalam kecenderungan implusive buying daripada mahasiswa dengan latar belakang pekerjaan orang tua sebagai Non-PNS. 


\section{KESIMPULAN}

Hasil penelitian menemukan kesimpulan bahwa apabila ditinjau dari latar belakang keluarga berdasarkan status orang tua, tidak ada perbedaan kecenderungan impulse buying pada mahasiswa ditinjau dari status orang tua (orang tua lengkap dan orang tua tunggal). Kesimpulan kedua, yaitu ada perbedaan kecenderungan impulse buying pada mahasiswa ditinjau dari latar belakang pekerjaan orang tua (PNS dan Non-PNS).

Saran kepada pihak-pihak yang ingin menyusun strategi pemasaran terkait impulse buying, dalam konteks pasar sasaran mahasiswa, ada baiknya mempertimbangkan faktor latar belakang pekerjaan orang tua (PNS dan Non-PNS). Untuk kepentingan penelitian selanjutnya, apabila ada peneliti yang tertarik untuk menggunakan topik atau studi kasus yang serupa sebaiknya dapat menggunakan tingkat error yang lebih kecil dengan melibatkan lebih banyak subjek penelitian.

\section{DAFTAR REFERENSI}

Ali, H. (2010, Agustus Kamis). Milenial Nusantara: Wajah Masa Depan Indonesia. Diambil kembali dari Koran Sindo: https://nasional.sindonews.com/read/1228911/18/milenial-nusantara-wajahmasa-depan-indonesia-1502307470.

Boyd, Walker, \& Larreche. (2000). Manajemen Pemasaran. Jakarta: Erlangga.

Cobb, C., \& Hoyer, W. (1986). Planned Versus Implusive Purchase Behaviour. Journal of Retailing, 62(4), 384-409.

Coley, A., \& Burgess, B. (2003). Gender Differences in Cognitive and Affective Impulse Buying. Journal of Fashion Marketing and Management, 7(3), 282295.

Gerungan, W. (2004). Psikologi Sosial. Bandung: PT. Rafika Aditama.

Herliyani, C. (2017). Kecenderungan Pembelian Implusif pada Mahasiswa Fakultas Ekonomi Kampus I Universitas Sanata Dharma Yogyakarta. Skripsi, Yogyakarta: Universitas Sanata Dharma.

Kotler , P. (2009). Manajemen Pemasaran (13 ed.). Jakarta: Erlangga. 
Kotler, P. (2005). Manajemen Pemasaran (11 ed.). Indonesia: Index Kelompok Gramedia.

Kotler, P., \& Gary, A. (2008). Prinsip-prinsip Pemasaran (12 ed.). Jkt, Erlangga.

Latief. (2015, April Selasa). Menunggu Kiprah Anak-anak Muda yang Jumlahnya Makin "Gemuk". Diambil kembali dari Kompas.com: https://edukasi.kompas.com/read/2015/04/28/11491251/Menunggu.Kiprah.A nak-anak.Muda.yang.Jumlahnya.Makin.Gemuk.

Mai, N., Kwon Jung, Garold , L., \& Sandra, G. (2003).An Exploratory Investigation into Implusive Buying Behavior in a Transnational Economy:a Study of Urban Consumer in Vietnam.Journal of International Marketing,11(2),13-35.

Moningka. (2016, Agustus). Konsumtif: antara Gengsi dan Kebutuhan. Diambil kembali dari Suara Pembaruan: http://www.Suarapembaruan.com. Diakses 1 November 2918.

Moschis, G. (1991). The role of family in consumer socialization of children and andolescent. Perpectives in Consumer Behavior (4 ed.).

Mowen, C., \& Michael, M. (2001). Perilaku Konsumen. Erlangga.

Mulyono, F. (2012). Faktor Demografis dalam Perilaku Pembelian Impulsif. Jurnal Administrasi Bisnis, 8. Diambil kembali dari https://media.neliti.com.

Puspitasari, P. (2014). Pengaruh Faktor Demografi dan Faktor Psikologis Terhadap Pengambilan Keputusan Investasi. Surabaya: Sekolah Tinggi Ilmu Ekonomi.

Santrock, J. (2003). Adolescence: Perkembangan Remaja. Edisi 6. Jakarta: Erlangga. (6 ed.). Jakarta: Erlangga.

Schiffman, L., \& Kanuk, L. (2000). Perilaku Konsumen. Jakarta: Indeks.

Setiadi, N. J. (2003). "Perilaku Konsumen. Bogor: Kencana.

Utami, R. (2011). Pengaruh Family Structure terhadap Materialisme dan Pembelian Kompulsif pada Remaja. Jurnal Manajemen Teori dan Terapan, 4(3).

Verplanken, B., \& Herabadi, A. (2001). Individual Difference in Impluse Buying.

Widayati, I. (2012). Faktor-Faktor yang Mempengaruhi Literasi Finansial Mahasiswa Fakultas Ekonomi dan Bisnis Universitas Brawijaya. Madiun: IKIP PGRI Madiun.

Widiyoko, Eko Putra. 2015. Teknik Penyusunan Instrumen Penelitian.Yogykarta: Pustaka Pelajar. 